\title{
Aspects Related to the Influence of Christianity on the Society \\ DOI: https://doi.org/10.47175/rissj.v2i2.215
}

\section{| Mihai Handaric |}

The Department of

Pentecostal Theology, "Aurel

Vlaicu" University of Arad,

Rumania

\begin{abstract}
In this paper the author analyzes the influence of Christianity on society. There will be demonstrated that through its structure, man was created to live in the community. He discovers himself by relating to the world surrounding him, as it is argued by Martin Heidegger, and Martin Buber. Here we also include the relationship with the transcendent. The philosophical and sociological arguments help us understand the influence Christianity had on European society. The religion of the European nations had a strong influence on the civilization of the continent and the world. Researchers have come to the conclusion that man was created with an innate religious feeling. Rudolf Otto sought to demonstrate that man's religious experience can only be explained by the aprioric existence of the sacred. So did Mircea Eliade, who introduced a new term "hierophany" to define the act of experiencing the sacred. There were also researchers who reinterpreted the relationship with the sacred. Emile Durkheim argued that ultimately, religion in its present form will be replaced by a so-called "civic religion," which will replace religious services in churches. Accepting the perspective of Scripture, the author tries to show the idea of the presence of Divinity in the believer's life (John 14:15-26). Jurgen Moltman asserts that if society were to enter the process of Christ's discipleship, she would discover the divine alternatives that bring the long-awaited results. Max Weber argued that Christian religion, and especially the sects of Protestantism, had a decisive role in influencing the culture and civilization of modern Europe, and the world at large. From his point of view, the decision of man in capitalist society to make a great effort in his work, has a religious motivation, namely, the doctrine of predestination. Considering that the moral and theological dimension of Christianity lies at the root of human significance, Christians struggle to defend the revealed message. A good example is given by Francis Schaeffer, who in his book Trilogy pleads to preserve the traditional moral values of the Bible. Schaeffer attempts to link the idea of revelation, as it is presented in the Christian Bible, with the discovering of man's significance.

KEYWORDS

christianity; society; sacred; ethical; europe; capitalism
\end{abstract}

\section{INTRODUCTION}

In this paper, we try to highlight certain aspects related to the influence of Christianity on society, taking into account the relationship between man and the environment in which he is. We will refer to the role of the Christian religion in Europe, but also to the modern period in the history of the nations of the world. We will seek to observe the close 
relationship between the modern civilization that was born in Europe and the religion of this continent. From a religious point of view, Europe identifies itself with Christianity the religion of the nations that live here (Johan Fornäs, 2012; H R Patapievici, 2015).

To begin with, we will explain the meaning of the term "Christian." The Scripture claims that for the first time this name was given to the disciples of Christ in Antioch. The author of the book Acts of the Apostles gives us some information about the context in which the disciples of Christ were called Christians. We read that after the persecution that broke out in Jerusalem against them, many of the Christians took refuge in other cities. " Now those who were scattered because of the persecution that took place over Stephen traveled as far as Phoenicia, Cyprus, and Antioch, and they spoke the word to no one except Jews." (Acts 11:19).

Some of them preached the Gospel only to the Jews. Those who converted from the Jews were still regarded as members of the Jewish religion. But others decided to proclaim the gospel to other nations. "Among them were some people from Cyprus and Cyrene, who came to Antioch, spoke to the Greeks, and preached the gospel of Jesus to them. The hand of the Lord was with them, and a great number of people believed and returned to the Lord (Acts 11:20-21).

Thus the first church of the Gentiles was formed in Antioch. Luke goes on to mention that " it was in Antioch that the disciples were first called "Christians." (Acts 11:26). At that time, Antioch was the second largest city in the Eastern Empire, and the third largest and city in the entire Roman Empire, after Rome and Alexandria. It numbered around 500 thousand inhabitants. Antioch became the headquarters of Paul's missionary journeys around 47-55 AD. ${ }^{1}$

\section{The Christian and the world}

As we noticed, the name "Christian" was given to people in the society in which the disciples lived. Christianity can be analyzed in relation to the world in which it manifests itself. Efforts to Christianize through the baptismal method have been noted to be successful in several countries (Taiwo, MT and Taiwo, VO, 2020)The man was created to live in community. This aspect is explained by Martin Heidegger in his book Being and Time ( Martin Heidegger, 2001) where he shows that man discovers himself through his relation to the world around him².

About the actual relationship between man and the surrounding world, the Jewish philosopher and theologian, Martin Buber, speaks in his famous book: I and Thou (Ich und Du in German) (Martin Buber, 1958). The author points out the radical distinction between two fundamental attitudes that people are capable of manifesting, namely: The relationship of type reciprocity: I-Thou, which occurs between people, and the type relationship: I-It, describing a subject-object type relationship, which implies a dose of control of the subject over the analyzed object which is in total passivity. "When man speaks I, he thinks of one of the two possibilities" (Martin Buber, 1992) mentioned above.

\footnotetext{
${ }^{1}$ About Antioch we read that „Antioch was the centre of the Seleucid kingdom until 64 BCE, when it was annexed by Rome and was made the capital of the Roman province of Syria... In the 4th century CE Antioch became the seat of a new Roman office that administered all the provinces on the empire's eastern flank." https://www.britannica.com/place/Antioch-modern-and-ancient-city-south-central-Turkey. Accessed 08.10.2019.

${ }^{2}$ See the section: „Excurs despre Fiinţă, Fiinţare şi Dasein”, from Martin Heidegger, trans. Thomas Kleininger, Repere pe drumul gândirii, Bucureşti: Editura Politică, 1988, p. 28-32.
} 
Normally any man is in a dialectical relationship, with one of the two situations. Any $I$ It type relationship can potentially be transformed into an I-Thou relationship, when a person's true personality is potentially manifested in his world. Here includes Buber also, the relationship with the Divinity, who he calls: "of the eternal Thou, the only I-Thou situation that man can sustain indefinitely; in it God is recognized in all things as the wholly other, not observed but revealing himself" (Buber, the-philosophy.com, 2019)

Concerning the relationship I-the eternal Thou, Buber says that based on the interaction between God and Israel, the rejection of the kingship of God whithout an intermediary, produced the idea of the election of a human king - the anointed one, and then "to the awaited Messiah who brings cosmic and eschatologica closure (Samuel H. Brody, 2018).

The explanations of philosophical and sociological nature, presented above, are the basis of the human relation to other people and to society. This types of attitude concerning human behavior, can be generally applied to our case. Existentially speaking, human interaction with the environment, gave birth to the civilization Christians produced, in the so called European society.

\section{Man and religious feeling}

I had previously talked about the relationship of man with the Divinity. Researchers have shown that man's relationship with the Divinity influences the way man relates to the society in which he lives. We are interested in the influence that the religion of the European nations has had on the modern society. In the first part of the 20th century, the concept of "sacred" dominated the study of comparative religions.

Nathan Soderblom, a historian of religions, argued in 1913 that the idea of "holiness" is the basis of religion. In order to understand the religious experience, we must consider the distinction that man makes between sacred and profane. The researchers concluded that man was created with an innate religious feeling. Man has a tendency to worship. Religion is considered a fundamental characteristic of man. Rudolf Otto writes a book entitled The Sacred in which he tries to show that the religious experience of man can be explained only by the a priori existence of the sacred (Rudolf Otto, 1992; Britannica, 2019).

Another specialist in the history of religions, Mircea Eliade, in his book: The Sacred and the Profane, takes the interpretation of the sacred, as described by Rudolf Otto. Eliade defines the sacred as a frightening and irrational experience of man. From his poit of view, man discovers

the feeling of fear when facing the sacred, that mysterium tremendum, the majestas that emanates an overwhelming power ... Otto designates all these experiences, naming the term numenous (from the Latin nomen, "god"), because they are determined by the revelation of a aspect of divine power. The numenous is a kind of ganz andere, something very special, which has nothing human or cosmic, and which gives to man the feeling of nothingness, making him feel himself as being "nothing more than a creature ... to use the words to Abraham when he addressed the Lord, only "dust and ashes" (Acts 18:27) (Mircea Eliade, 1995, p. 8)

Eliade goes a step further in his investigations, seeking to define the actual man's encounter of the sacred. He introduces the word "hierophany" to explain this experience. The meaning of the term is present in the etymology of the word, namely: ,the appearing of something as sacred to us." From his point of view the history of religions, from the most primitive to the most elaborate, is made up of an accumulation of hierophanies manifestations of sacred realities. From the most elementary hierophany, as for example, the manifestation of the sacred in some thing, a stone or a tree, to the supreme hierophany 
which is, for a Christian, the incarnation of God in Jesus Christ, there is no rupture (Mircea Eliade, 1995, p. 9).

Based on the statements made by Eliade we could argue that the influence of the sacred is present also in what we call the Modern Period. We will discuss this aspect later in our paper, when we will refer to Max Weber's sociological perspective on the birth of Capitalism (Max Weber, 2003, 2007).

However, the researchers from the first part of the 20th century also came up with an alternative explanation for the idea of the perception of the sacred by the human being. Emile Durkheim considered the founder of functionalist theory, studied religions especially practiced in smaller human communities, such as totemism, and recorded his observations in the book: The Elementary Forms of the Religious Life, (Emile Durkheim, 2008) considered to be the best-known study in sociology of religion. He argued that religion influences the thinking and behavior of community members who practice it. Durkheim observed that people tend to make a clear distinction between religious symbols, objects and rituals, and profane symbols, objects, and practices. For man, sacred things have divine characteristics, possessing special powers. This behavior is also true with reference to the most advanced cultures and societies.

He argues that religion is not only concerned with beliefs, but also involves certain rituals. Together, they strengthen community solidarity. In this way the community escapes from daily experience and lives in higher areas of experience. He predicted that as society modernizes, the influence of religion will decrease in influence, because scientific thinking will replace religious thinking. From his point of view, the idea of "God" is disappearing. Durkheim tries to demonstrate that there is a close relationship between the instability of the industrial society and the decline of religion. The state is from his point of view the ultimate moral force in society (Emile Durkheim, 2018).

Durkheim proposes the so-called "civic religion", which will replace religious services in churches. Common activities in society, such as: civil society events, parades, patriotism will replace religious rituals (Durkheim and functionalism, Cliffnotes, 2019). He criticizes Friedrich Schleiermacher for being too subjective, saying that religion is: "consciousness of absolute dependence on God" ("The Sacred," Britannica, 2019)' This idea was later developed by Max Sheler, who tried to combine the interests of empirical scientists with those of nineteenth-century philosophers. Speaking about the role of religion, Sheler says that revelation is an intentional relationship with the transcendent, is infinite in meaning, and is experienced by the individual (Stanford Encyclopaedia, 2014). But since the first quarter of the twentieth century, many historians of religion have agreed that: places, events, sacred things, holy people, are the fundamental aspects of religious life, if not the essential reality of religious life ("The Sacred," Britannica, 2019).

To a certain extent, Radu Carp finds a middle ground between Weber's and Durkheim's views on the role of religion in society. He argues that religion is not "just a system of ideas and beliefs (as Weber believed), but also a 'system of action' that involves symbolic ceremonies ... But industrial societies are characterized for Durkheim by 'functional differentiation', in the sense that different organizations or individuals act in the field of health, education, politics, etc., occupying the place that usually the Church plays" (Radu Carp, 2009).

As an observation to Durkheim's perspective, and taking into account the conclusions reached later by specialists in the history of religions, we will say that religion is based on the hope offered by revelation. We cannot limit the presence of beliefs or rituals in a comunity, without considering the presence of hope behind them. Karl Barth noticed this 
aspect in the same period in which Durkheim wrote his book, in his commentary on the Epistle to the Romans, after the unhappy experience of the First World War (Karl Barth, 1933).

Christ Himself urged the apostles to accept the idea of the presence of the Divinity in the life of the believer.

If you love Me, you will keep My commandments. And I will ask the Father, and he will give you another Comforter (Greek: Paraclete, defender, helper.), Who shall abide with you for ever; that is, the Spirit of truth, whom the world cannot receive, because she does not see him and does not know him; but you know him, because he abides with you, and will be in you ... He that hath my commandments, and keepeth them, he loveth me; and he that loveth me shall be loved by my Father. I will love him, and I will show Myself to him ... But the Comforter, that is, the Holy Spirit, whom the Father will send in My Name, will teach you all things, and will remind you of all that I have told you I. (John 14: 15-26).

The Lord Jesus assures the disciples that after He departs from their midst, they will do great works, even greater than $\mathrm{He}$ has done. "Verily, verily, I say unto you, He that believeth on me shall do the works that I do; but he will yet make others greater than these "(John 14:12), because He will be with them.

The Apostle Paul decides to pray for the believers in Ephesus, precisely so that they understand and experience the mystery of God's presence in them.

Yes, to me, who I am the most insignificant of all the saints, this grace has been given, to proclaim to the Gentiles the unfathomable riches of Christ ... Here, therefore, I say, I bow my knees before the Father of our Lord Jesus Christ, ... and I pray that, according to the riches of His glory, He will make you to be strengthened in power, by His Spirit, in the inward man, ... that you may be filled with the fullness of God (Ephesians 3: 819).

We will continue to observe that sociologists and theologians are trying to testify in favor of the importance for the involvement of Christians in society, as mentioned by Christ (Weber, Moltmann, etc.).

Jurgen Moltmann, in his book, God for a Secular Society, strongly argues that Christian discipleship through dedication and solidarity can be a way for redemption, in spite of its values which are usually contested (Jurgen Moltmann, 1999). Christianity is the solution for gaining messianic hope, in the thorniest political and ecological issues, globalization, the capitalist market economy. He noted that prominent representatives of society were often skeptical about the implementation of Christian ethics in the community (Jurgen Moltmann, 1999, p.49). However, Moltman argues that if society enters the process of Christ's apprenticeship, she will discover the divine alternatives that bring the long-awaited results (Jurgen Moltmann, 1999, p.197).

\section{Christianity and modernity}

One of the most important sociologists of the twentieth century, Max Weber concluded that the Christian religion, and especially the Protestant sects, had a decisive role on the development of modern European civilization and culture, and of the world in general. Weber is considered today "one of the leading theorists of modernity, whether this is conceived as a social, economic, political, or cultural phenomenon"3

\footnotetext{
${ }^{3}$ See the preface to the book, of Max Weber, Economy and Society: A New Translation, Cambridge, Massachusetts: Harvard University Press, 2019, p. viii.
} 
Weber noticed that "only in the West is there 'science' reached the stage that we know today as 'valid' ... despite all the initial attempts in India (Mimamsa school) ... in Asia Minor ... only the West knows a discipline as it is Canonical law. This is the way things are in art too ... Only in the West there is rational harmonious music - counterpoint and harmony ... only in the West were sonatas, symphonies, operas" (Max Weber, 2007, pp. 57).

Weber says that the determination of the man in the capitalist society to make a special effort in his work has an ethical motivation. "Someone might be inclined to believe that these personal moral qualities would have nothing to do with any ethical maxim or even any religious idea, ... rather liberal 'enlightenment' - it is the right basis for a commercial lifestyle. Indeed, nowadays this is the case, and in general. Not only is there usually no relation between the way of life and its religious basis (Max Weber, 2007, p. 55).

From his point of view, in the case of man, the idea of vocation contains an irrational element, which is based on the religious conception, namely that to man was assigned a mission "by God" (Max Weber, 2007, p. 59) He states that "the historical bearers of ascetic Protestantism are mainly the following four: Calvinism in the form it took in the main western-European regions of its domination, especially in the seventeenth century; pietism; Methodism; the sects that originate in the Anabaptist movement" (Max Weber, 2007, p. 108).

More precisely" the doctrine of predestination, which is formulated in the seventeenth century in the great synods of that time, from Dordrecht and Westminster, was the basis of continuous activism" (Max Weber, 2007, p. 112).

Motivated by this doctrine they understood that "God desires the social work of the Christian, for He wants that the social life to be in accordance with His commandments, so as to meet this purpose. The social work of Calvinism in this world is only the 'majorem Dei gloriam' work" (Max Weber, 2007, p. 119). The principle of self-sacrifice in capitalism represented for Calvinist sects a way of regaining the state of being elected by God, lost through the fall of man into sin.

From the point of view of Radu Carp, even in the present, in Europe religion influences all national public spheres "even if the religious actors are not recognized to the same extent ... the legitimacy of public interventions ... Thoughts and feelings developed in the private sphere of the individual, inevitably leads to practical actions and consequences in the public sphere" (Radu Carp, 2009, p.49).

\section{Christianity and revelation}

As we have seen, researchers have discovered that in Europe, we may see a direct relationship between social involvement and faith. We saw that Christian morality had an important role for the birth of capitalism, the morality which was dictated by Scripture considered divine revelation for man.

The consistency with this revelation brought the results mentioned above. That is why Christianity is fighting for the right understanding of the biblical message. One such defender of the revealed message is Francis Schaeffer, who writes an apology in favor of the Gospel, known as The Trilogy (Francis Schaeffer, 1992). The author pleads for fidelity to the moral values contained in the Bible. He defends the traditional perspective of biblical values, in the context of an increasingly secularized human society. To better understand Schaeffer's perspective on the relationship between Christianity and morality, we consider it beneficial to meet the author and the motivations that underpinned this book. 
In this sense we recall the description of the author, by J.I. Packer, who prefaces the aforementioned book (Francis Schaeffer, 1992, p. 13). Packer describes him as a man "living in the present, learning from the past and looking to the future" (Francis Schaeffer, 1992, p. 13). In this way he was able to present the vision of "eternal truth." He sought to speak the truth perseveringly and without compromise, to those who experienced failure as a result of personal trust in the "relativism, irrationalism, fragmentation and nihilism of our culture today" (Francis Schaeffer, 1992, p. 14). Schaeffer is described as having the following specific traits: a unitary image on human life in harmony with the message of Scripture, a strong belief in the force of rational arguments in explaining the Christian perspective on the reality of life (Francis Schaeffer, 1992, p. 14).

Schaeffer speaks of the need for revelation, in searching for the meaning of life, in the philosophical and theological discourse. To this end, he remembers Heidegger, who changed his existentialist philosophical conception, in the latter part of life, to make room for the idea of revelation. Schaeffer calls the new perspective of Heidegger: "the mysticism of language." The philosopher hoped that man would discover the meaning of life through language. The language, from Heidegger's point of view, could make known the "impersonal" that is beyond himself. At the basis of his new conception are the following premises: "(1) something, the Being, exists; (2) this something becomes known; (3) the language is one with the Being and makes the Being known. We can never rationally know what exists (obvious fact), but language reveals that something exists ... Thus, the man who speaks becomes the spokesman of the impersonal "What is" (the Being). The impersonal and unknown Being, speaks through the being who utters (verbalizes) - namely: the man" (Francis Schaeffer, 1992, p. 49).

Schaeffer goes further with Heidegger's reasoning, saying that what the philosopher says could be correct "if there would be a personality beyond man that could say something meaningful to man and through man." But Heidegger does not accept that "a person beyond man speaks to him." That is why he remains "locked in his special form of mysticism. The word language is a connotative word that seems to imply the idea of a person" (Francis Schaeffer, 1992, p. 49). Schaeffer seeks to link the idea of revelation, as presented in the Christian Bible, with man's need for meaning.

As we have seen from Weber's case study, the written Christian revelation, expressed through the doctrine of election from Protestantism, specifically in Calvinism, led from his point of view, to the emergence of modern culture and civilization in Europe.

\section{CONCLUSION}

In this paper I analyzed the influence of Christianity on society. I understood that through its structure, man was created to live in community. He identifies himself in connection to the world around him (Heidegger). Martin Buber, in his book I and You demonstrated that in his interaction, man manifests two fundamental attitudes, namely: The type reciprocity relationship: I-You, which takes place between people, and the type relationship: I-It, which describes a subject-object relationship. The philosophical and sociological explanations reinforce our argument supporting the results that Christianity has produced in European society.

We understood that the relationship of the Christian community with the Divinity, influenced the European society. The religion of the European nations had a strong influence on the civilization of the continent and of the world. The researchers concluded that man was created with an innate religious feeling. 
Rudolf Otto tried to demonstrate that the religious experience of man can be explained only by the a priori existence of the sacred. Likewise, Mircea Eliade, in his book The Sacred and the Profane, defined the actual experience of man with the sacred, introducing the term "hierophany." These hierophanies are present for human comunities of all time, whether they are more primitive or more complex.

There were also researchers who reinterpreted the relationship with the sacred. Emile Durkheim, considered the founder of functionalist theory, argues in his work: The Elementary Forms of the Religious Life, that finally, religion in its current form will be replaced by a so-called "civic religion", which will replace religious services in churches. Civil society events, parades, patriotism will replace religious rituals. We argued that we cannot limit ourselves to a faith or rituals that eliminate the supernatural dimension, which nourishes human hope.

Scripture encourages us to accept the idea of the immediate presence of the Divinity in the life of the believer (John 14:15-26). That is why Paul speaks a prayer for the believers in Ephesus, that they may understand the mystery of God's presence in them (Ephesians 3: 8-19). Jurgen Moltman said that if society were to enter into the process of Christ's apprenticeship, he would discover the divine alternatives that bring the long-awaited results.

Max Weber argued that the Christian religion, and especially the Protestant sects, played a decisive role on modern European culture and civilization, and the world at large. From his point of view, the decision of man in the capitalist society to make a special effort in his work, has an ethical motivation, namely, the doctrine of predestination. The sustained effort of these Christians was to regain the state of being elected by God, which was lost through the fall of man.

Considering that the moral and theological dimension of Christianity is the basis of human significance, Christians fight to defend the revealed message. An illustrative example is given by Francis Schaeffer, who in his book Trilogy pleads for fidelity to the moral values contained in the Bible. He defends the traditional perspective of biblical values, in the context of an increasingly secularized human society. He tried to present the vision of "eternal truth." Schaeffer advocated a unitary image of human life in harmony with the message of Scripture, a strong belief in the force of rational arguments to explain the Christian perspective on the reality of life. He tries to prove that even in philosophy, man expects a revelation that will communicate something to him about the meaning of life. Thus, Schaeffer attempts to link the idea of revelation, as presented in the Christian Bible, with the human need for significance. This has been demonstrated by Weber, who argues that the doctrine of election from Calvinism had a direct influence to the emergence of modern culture and civilization in Europe.

\section{REFERENCES}

Antioch. (2019). Modern And Ancient City, South-Central Turkey. Retrievied from https://www.britannica.com/place/Antioch-modern-and-ancient-city-south-central-Turkey.

Barth, Karl. (1933). The Epistle to the Romans, Oxford, London, New York: Oxford University Press, 1-26.

Brody, Samuel H. (2018). Martin Buber's Theopolitics, Bloomington: Indiana University Press, 84.

Buber, Martin. (1958). I and Thou, New York: Charles Scribner's Sons, $2^{\text {nd }}$ Ed., Buber, Martin. (1992). I and Thou, tras Ştefan Aug. Doinaş, Bucureşti: Humanitas, 29.

Bube. (2019). Martin: Biography. Retrievied from 
https://www.the-philosophy.com/buber-i-thou-summary.

Bube. (2019). Durkheim and functionalism. Retrievied from

https://www.cliffsnotes.com/study-guides/sociology/religion/sociological-theories-ofreligion.

Carp, Radu. (2009). Dumezeu la Bruxelles. Religia în spațiul public european, ClujNapoca, Eikon,.

Durkheim, Emile. (2008). The Elementary Forms of the Religious Life, trans, Joseph Ward Swain, New York, Dower Publications.

Durkheim, Emile. (2018). Professional Ethics and Civic Morals, Chicago \& London: University of Chicago Press, 1973, republished by Routledge.

Eliade, Mircea. (1995). Sacrul şi profanul, trad. Brînduşa Prelipceanu, Bucureşti: Humanitas, 8.

Fornäs, Johan. (2012). Signifying Europe, Bristol, Chicago: Intellect Books, University of Chicago Press.

Heidegger, Martin, trans. Dorin Gabriel Tilinca. (2001). Fiire şi timp, Cluj-Napoca: Editura, Grinta.

Heidegger, Martin, trans. Thomas Kleininger. (1988). Repere pe drumul gândirii, Bucureşti: Editura Politică.

H R Patapievici. (2019). Europa si crestinismul. Retrievied from https://www.youtube.com/watch?v=NXorm2GO0Qg, on 15 oct. 2015

Moltmann, Jurgen. (1999). God for a Secular Society: The Public Relevance of Theology, Fortress Press.

Otto, Rudolf. (1992). Sacrul, Bucureşti: Humanitas.

Schaeffer, Francis. (1992). Trilogia, Oradea: Casa Cărţii.

Scheler, Max. (2019). din Stanford Encyclopaedia of Philosophy. Retrievied from https://plato.stanford.edu/entries/scheler/.

Taiwo, Matthew T and Taiwo, Victor O. (2020). Religion Sectarianism in Yoruba Land and Threats to Its Millennial Tribal Union. Randwick International of Social Science Journal, 1 (2), 165-173. DOI:https://doi.org/10.47175/rissj.v1i2.41

Weber, Max. (2007). Etica protestantă şi spiritul capitalismului, Bucureşti: Humanitas, 2003.

Weber, Max. (2019). Economy and Society: A New Translation, Cambridge, Massachusetts: Harvard University Press. 